\title{
INSTRUMENTAL INSEMINATION \\ OF HONEY BEE QUEENS DURING FLIGHT ACTIVITY PREDISPOSITION PERIOD 2. NUMBER OF SPERMATOZOA IN SPERMATHECA
}

\author{
Dariusz Gerula, Beata Panasiuk, \\ Pawel Węgrzynowicz, Małgorzata Bieńkowska \\ Research Institute of Horticulture, Apiculture Division, Kazimierska 2, 24-100 Puławy, Poland \\ e-mail: dariusz.gerula@man.pulawy.pl
}

Received 02 April 2012; accepted 17 May 2012

$\mathrm{S}$ u m m a r y

The effect of the instrumental insemination of honeybee queens after they performed their orientation flight or attempted to perform the flight, on the number of sperm in the spermatheca was observed. Naturally mated queens and instrumentally inseminated queens were examined. Queens were instrumentally inseminated under one of the following 4 circumstances: the instrumentally inseminated queens were either 7 day olds and had been given either a short or long- $\mathrm{CO}_{2}$ treatment, or they were inseminated after the trial flight or after returning from the orientation flight. Queens from the various groups had a similar number of spermatozoa in their spermatheca (on average, from 4.7 to 5.3 million). The number of spermatozoa filling the spermatheca influenced both the color and the texture of spermathecae. Significant differences in the number of spermatozoa were stated. Instrumentally inseminated queens that did not lay eggs had significantly less spermatozoa in their spermathecae $(3.9 \mathrm{mln})$ than egg laying queens $(5.5 \mathrm{mln})$.

Keywords: honeybee, number of sperms, spermatheca, instrumental insemination, flight activity, natural mating, texture and color of spermatheca.

\section{INTRODUCTION}

One of the indicators of a queen's readiness for mating and semen admission are the orientation flights. Instrumental insemination of bee queens when they are ready for the mating flight or after the orientation flight, does not significantly affect acceleration of oviposition. When queens are inseminated at the above mentioned period, the percentage of queens that start laying eggs is slightly higher than among queens inseminated at a scheduled time (Gerula et al., 2011). The most secure way to accelerate oviposition of instrumentally inseminated queens is to treat them with $\mathrm{CO}_{2}$ gas (Mackensen, 1947; Ebadi and Garry, 1980; Kaftalongu and Peng, 1982; Janoušek, 1987; Konopacka, 1991; Gerula et al., 2011). The earlier oviposition, however, does not directly depend on the number of spermatozoa in the spermatheca of queens. Kaftalongu and Peng (1982) reported that even non-inseminated queens treated with $\mathrm{CO}_{2}$ gas started laying unfertilized eggs.

Properly inseminated honey bee queens have from 3 to 5 million spermatozoa in their spermathecae (Mackensen and Roberts, 1948; Woyke, 1960, 1979; Woyke and Jasiński, 1979). Many factors influence this number. One of them is the age of the bee queen at the time of insemination. Woyke and Jasiński (1976) recommend inseminating queens when they are 5-7 days old, while Mackensen (1964) recommends 7-10 days old. Another important factor that guarantees the success of insemination is the appropriate temperature in which queens should be kept before and after 
the treatment. The right temperature is preferably the temperature of the nest. Queen contact with worker bees during the first 48 hours after the insemination when spermatozoa migrate from the oviducts to the spermathecae, is important as well (Laidlaw, 1954; Mackensen, 1964; Woyke and Jasiński, 1973; Woyke, 1979). The volume of semen introduced into queen oviducts, the number of semen doses, and quality of semen used for insemination influences the number of spermatozoa entering the spermathecae (Woyke, 1960; Woyke and Jasiński, 1978; Prabucki et al., 1987; Gontarz et al., 2005; Bieńkowska et al., 2008). The diameter of the insemination needle tip also influences the success of the insemination (Bieńkowska and Panasiuk, 2006).

In the case of naturally mated queens, the number of spermatozoa in the spermatheca mostly depends on the number of matings, which is associated with the number of copulating drones (Woyke, 1960). The number of spermatozoa in the spermathecae of naturally mated queens is higher than in instrumentally inseminated queens (Mackensen and Roberts, 1948; Woyke, 1960; Harbo, 1986; Wilde, 1994).

The filling of spermatheca can be organoleptically assessed. After the removal of tracheal tissue, the color shade and density of the spermatheca indicate the reproductive status of the queen. In the virgin queen, the color is crystal clear. The spermatheca of a well-mated queen is the color of drone semen; a creamy, coffee latté color with a pattern of marbled swirls. A cloudy or milky whitish appearance, indicates an inadequate supply of semen (Cobey, 2012; Glenn, 2012).

The aim of this study was to check whether the honeybee queens instrumentally inseminated at the time when they are starting to prepare for their first flights, or after the first flights, have the same number of spermatozoa in their spermatheca than in queens inseminated at a scheduled time, regardless of the flight activity.

\section{MATERIAL AND METHODS}

The study was performed in 20072008 and in 2010, in the Department of Apiculture, The Research Institute of Horticulture (previous name: The Research Institute of Pomology and Floriculture) in Puławy, Poland.

Altogether, 133 Caucasian honeybee queens were investigated. The queens were either naturally mated or instrumentally inseminated. They were kept in 3-skewer trapezoidal styrofoam mating nuclei with a capacity of about $1.5 \mathrm{dm}^{3}$. Previously, a test was done on queens instrumentally inseminated when preparing for their first flights, or after the first flights, to check to see if they began oviposition earlier than queens inseminated at a scheduled time, regardless of the flight activity (Gerula et al., 2011).

Five groups of queens were used: a group for natural mating, and 4 groups for instrumental insemination at different ages and with different treatment with $\mathrm{CO}_{2}$ gas. Queens were instrumentally inseminated with a dose of $8 \mu \mathrm{l}$ of semen. Semen was collected from mature, free flying drones, caught at the entrance of the hives.

- Queens naturally mated presented the control group (NM),

- Queens instrumentally inseminated, at the age of 7 days and treated with long $\mathrm{CO}_{2}$. The treatment lasted 3 minutes during insemination and 3 minutes two days later (II7CO $2 \mathrm{~L}$ ),

- Queens instrumentally inseminated at the age of 7 days and treated with short $\mathrm{CO}_{2}$. The treatment lasted for only about 30 seconds. This was just sufficient time to immobilize the queen for semen injection (II7CO $\mathrm{O}_{2} \mathrm{~S}$ ),

- Queens instrumentally inseminated after their first flight and treated with short $\mathrm{CO}_{2}$ (30 seconds) (IIa1F),

- Queens instrumentally inseminated after the first attempt to fly and treated with short $\mathrm{CO}_{2}$ (30 seconds) (IItMF).

Queens from the 1.NM group were released for a free flight as they attempted to leave the mating hive, regardless of the number of their attempts to fly. Queens 
from the 4.IIa1F group were released for a free flight only on the first attempt. If the queens did not have a mating sign after returning from the first flight, they were then instrumentally inseminated. The queens that returned with the mating sign were eliminated from the experiment. Queens of the 5.IItMF group were instrumentally inseminated when observed at the covered runway in the nuclei entrance as they tried to perform the flight. Observations of queens at the nucleus entrances were conducted each day from the $5^{\text {th }}$ to $35^{\text {th }}$ day of their life. The observations started from 12:00 until the end of the queens' flight activity.

Age of queens at the time of instrumental insemination and the age at the start of oviposition as well as the time duration from queen insemination to the onset of oviposition were determined.

The time that eggs appeared in the mating nuclei was noted daily, starting from the second day after the insemination. This observation continued until the queens started laying eggs or were 41 days old. Queen excluders were left on the entrances until the end of the experiment.

The queens were killed and dissected after starting oviposition, when the brood of the worker bees was capped. The queens that did not start laying eggs were killed at the age of 41 days when the experiment was finished. The spermatozoa were counted according to the method described by Bieńkowska et al. (2008). The tracheal tissue was removed from the spermathecae and the texture and color of the spermathecae were determined before counting the spermatozoa.This procedure was performed for 96 honey bee queens. When there was an absence of clear spermathecae, only the color was taken into consideration. There were 5 types of spermathecae: transparent or slightly hazy, white, with a granular structure in three different variants- granular creamy, granular white and granular glassy.

For the data analysis of the number of spermatozoa in the spermathecae, ANOVA was used. Two-factor ANOVA analysis was used to detect interaction between texture and/or color (external appearance) of the spermatheca and insemination technique, on the number of sperm in a spermatheca. For the statistical analysis of the number of sperms in the spermathecae of egg laying and non-egg laying queens, the Student's t-test was used.

\section{RESULTS}

\section{Number of spermatozoa in the spermatheca of queens}

Spermatozoa in the spermathecae of all experimental individuals, were counted in both laying and non-laying queens. Queens of various groups had a different average number of spermatozoa, which ranged from 0 to $9.125 \mathrm{mln}$. The highest number was found in the $3 . I I 7 \mathrm{CO}_{2} \mathrm{~S}$ group

Table 1 .

Number of spermatozoa in the spermathecae of naturally mated queens, instrumentally inseminated queens regardless or according to the flight activity

\begin{tabular}{|c|c|c|c|c|c|}
\hline \multirow{2}{*}{ Groups of queens* } & \multirow{2}{*}{$\begin{array}{c}\text { No. of } \\
\text { queens }\end{array}$} & \multicolumn{4}{|c|}{ Number of sperms in the spermatheca $(\mathrm{mln})$} \\
\hline & & Min & Max & Mean $^{* \star}$ & SD \\
\hline 1.NM & 21 & 0 & 8.950 & $4.892 \mathrm{a}$ & 2.525 \\
\hline 2.II7CO $2 \mathrm{~L}$ & 16 & 2.000 & 7.300 & $4.856 a$ & 1.585 \\
\hline $3.117 \mathrm{CO}_{2} \mathrm{~S}$ & 24 & 2.050 & 9.125 & $5.331 \mathrm{a}$ & 1.815 \\
\hline 4.IltMF & 43 & 1.600 & 7.133 & $4.812 \mathrm{a}$ & 1.385 \\
\hline 5.lla1F & 29 & 2.650 & 8.300 & $4.770 \mathrm{a}$ & 1.454 \\
\hline Total & 133 & 0 & 9.125 & 4.914 & 1.710 \\
\hline
\end{tabular}

*1.NM-queens naturally mated, 2.II7 $\mathrm{CO}_{2} \mathrm{~L}$ queens instrumentally inseminated at the age of 7 days, and treated with long $\mathrm{CO}_{2}, 3$.II7 $\mathrm{CO}_{2} \mathrm{~S}$ queens instrumentally inseminated at the age of 7 days old, and treated with short $\mathrm{CO}_{2}$, 4.IItMF queens instrumentally inseminated after the effort to perform a $1^{\text {st }}$ flight, 5.IIa1F queens instrumentally inseminated after their $1^{\text {st }}$ flight;

$* *$ different letters indicate significant differences at $\alpha=0.05, \mathrm{~F}(4,128)=0.443, \mathrm{p}=0.776$. 
(above $5 \mathrm{mln}$, on average). Other queens had less than $5 \mathrm{mln}$ spermatozoa in their spermathecae, but significant differences between the groups were not found (Tab. 1).

Three queens from the 1.NM group had an extremely low number of spermatozoa in their spermathecae. One of them (NM/17/2008) returned from her mating flight with a mating sign, however the spermatheca was empty. Two others (NM/71/2007, NM/65/2007) mated, but they had only 0.4 and $0.35 \mathrm{mln}$ spermatozoa in their spermathecae. Both queens had suffered some leg injuries and visible signs of being balled by the bees. Nevertheless, they were included in the experiment. The variability of spermatozoa number in the 1.NM queen group was higher than in the remaining groups.

The appearance of the spermatheca, way of insemination, and length of the $\mathrm{CO}_{2}$ treatment determining the number of spermatozoa in the spermatheca

The texture and color of the spermatheca determined the differences in the number of spermatozoa in the spermatheca (Tab. 2). The lowest number of spermatozoa was in transparent or slightly hazy colored spermathecae. This was the type of spermatheca that 4 queens had, and the average number of their spermatozoa

Table 2 .

Number of spermatozoa in the spermatheca according to the appearance of the spermatheca in naturally mated and instrumentally inseminated queens

\begin{tabular}{||c|c|c|c|c|c||}
\hline \multirow{2}{*}{ Appearance of spermatheca } & \multirow{2}{*}{$\begin{array}{c}\text { No. of } \\
\text { queens }\end{array}$} & \multicolumn{4}{|c|}{ Number of spermatozoa in the spermatheca $(\mathrm{mln})$} \\
\cline { 3 - 6 } & & Min & Max & Mean $^{*}$ & SD \\
\hline Transparent or slightly hazy & 4 & 0 & 2.050 & $0.700 \mathrm{a}$ & 0.917 \\
\hline White & 13 & 1.600 & 6.650 & $3.780 \mathrm{~b}$ & 1.419 \\
\hline Granular and creamy & 64 & 2.350 & 8.950 & $4.878 \mathrm{~b}$ & 1.450 \\
\hline Granular and white & 12 & 3.300 & 7.000 & $5.312 \mathrm{bc}$ & 1.061 \\
\hline Granular and glassy & 3 & 5.400 & 7.250 & $6.616 \mathrm{c}$ & 1.053 \\
\hline Total & 96 & 0 & 8.950 & 4.711 & 1.680 \\
\hline
\end{tabular}

*different letters indicate significant differences at $\alpha=0.05, \mathrm{~F}(4,91)=12.091, \mathrm{p}<0.01$.

Table 3 .

Number of spermatozoa in the spermathecae of queens that started laying eggs and did not start laying eggs up to the age of 41 days

\begin{tabular}{|c|c|c|c|c|}
\hline \multirow{2}{*}{ Queen groups* $^{*}$} & \multirow{2}{*}{$\begin{array}{c}\text { No. of queens: egg laying } \\
\text { Non-egg laying }\end{array}$} & \multicolumn{3}{|c|}{ Number of spermatozoa in the spermatheca $(\mathrm{mln})$} \\
\hline & & Mean & SD & Statistics \\
\hline \multirow{2}{*}{ 1.NM } & 18 & $5.666 \mathrm{~b}$ & 1.749 & \multirow{2}{*}{$t=5.242, d f=19, p<0.01$} \\
\hline & 3 & $0.250 a$ & 2.179 & \\
\hline $2.117 \mathrm{CO}_{2} \mathrm{~L}$ & N/A & $\mathrm{N} / \mathrm{A}$ & $\mathrm{N} / \mathrm{A}$ & $\mathrm{N} / \mathrm{A}$ \\
\hline \multirow{2}{*}{ 3.II7CO $2 \mathrm{~S}$} & 11 & $6.354 b$ & 1.518 & \multirow{2}{*}{$t=2.929, d f=22, p<0.01$} \\
\hline & 13 & $4.465 a$ & 1.619 & \\
\hline \multirow{2}{*}{ 4.IItMF } & 30 & $4.972 \mathrm{a}$ & 1.260 & \multirow{2}{*}{$t=1.156, d f=41, p=0.254$} \\
\hline & 13 & $4.442 \mathrm{a}$ & 1.631 & \\
\hline \multirow{2}{*}{ 5.lla1F } & 15 & $5.746 b$ & 1.239 & \multirow{2}{*}{$t=5.195, d f=27, p<0.01$} \\
\hline & 14 & $3.725 a$ & 0.789 & \\
\hline \multirow{2}{*}{ Total $^{\star *}$} & 74 & $5.503 \mathrm{~b}$ & 1.482 & \multirow{2}{*}{$t=5.3227, d f=115, p<0.01$} \\
\hline & 43 & $3.923 a$ & 1.689 & \\
\hline
\end{tabular}

*1.NM - queens naturally mated, 2.II7CO $\mathrm{CO}_{2} \mathrm{~L}$ queens instrumentally inseminated at the age of 7 days, and treated with long $\mathrm{CO}_{2}, 3$.II7 $\mathrm{CO}_{2} \mathrm{~S}$ queens instrumentally inseminated at the age of 7 days old, and treated with short $\mathrm{CO}_{2}$, 4.IItMF queens instrumentally inseminated after the effort to perform a $1^{\text {st }}$ flight, 5.IIa1F queens instrumentally inseminated after their $1^{\text {st }}$ flight;

$* * 2$.II7CO $\mathrm{L}$ - excluded group. 
was $0.7 \mathrm{mln}$. Three of these queens laid unfertilized (drone) eggs and one did not start oviposition although her spermatheca was filled with $2.050 \mathrm{mln}$ of spermatozoa.

There was no interaction between the texture and/or color of a spermatheca and technique of insemination on the number of sperm in the spermatheca (Fig. 1). Both, the texture and the color of spermatheca and the number of spermatozoa in spermatheca were not dependent on the insemination technique.

When only the method of queen insemination was taken into account, the naturally mated individuals had slightly less spermatozoa in their spermatheca (average $4.892 \mathrm{mln}, \mathrm{n}=21$ ) than instrumentally inseminated queens (average $4.918 \mathrm{mln}, \mathrm{n}=112$ ). No statistical differences between the averages were found $\mathrm{T}(131)=-0.063, \mathrm{p}=0.949$.

Queens were analyzed according to the duration of $\mathrm{CO}_{2}$ treatment during insemination. No statistical differences were found between the number of spermatozoa in the spermatheca of queens treated with $\mathrm{CO}_{2}$ for different time and the queens that were not anesthetized $(\mathrm{F}(2,130)=0.014, \mathrm{p}=0.985) . \quad$ Naturally mated queens that were not treated with $\mathrm{CO}_{2}$ gas $(\mathrm{n}=21)$ had $4.892 \mathrm{mln}$ spermatozoa in their spermatheca. Queens that were treated with $\mathrm{CO}_{2}$ gas for $30 \mathrm{~s}$ (3.II7CO $\mathrm{CO}_{2}$, 4.IItMF, 5.IIalF, $\mathrm{n}=96$ ) had, on average, $4.929 \mathrm{mln}$ spermatozoa in their spermatheca. The queens that were treated with long, 6 min $\mathrm{CO}_{2}$ (group 2.II7CO $2 \mathrm{~L}$, $\mathrm{n}=16$ ) had $4.856 \mathrm{mln}$ spermatozoa.

Number of spermatozoa in the spermathecae of egg laying and non-egg laying queens

Three queens in the naturally mated group (1.NM) were considered to be non-laying, although they returned to the hive with the mating sign. One of them did not start laying eggs, the remaining two laid unfertilized eggs. Queens from the $2 . \mathrm{IICO}_{2} \mathrm{~L}$ group were omitted in this calculation as each dissected and checked queen was laying eggs.

There was a similar number of spermatozoa only in laying and nonlaying queens from the 4.IItMF group. Other groups of egg laying queens had significantly more spermatozoa in their spermathecae than non-egg laying queens (Tab. 3). Egg laying queens had, on average, $1.6 \mathrm{mln}$ more of spermatozoa in their spermathecae, but the greatest disparity was observed in the 1.NM group of queens.

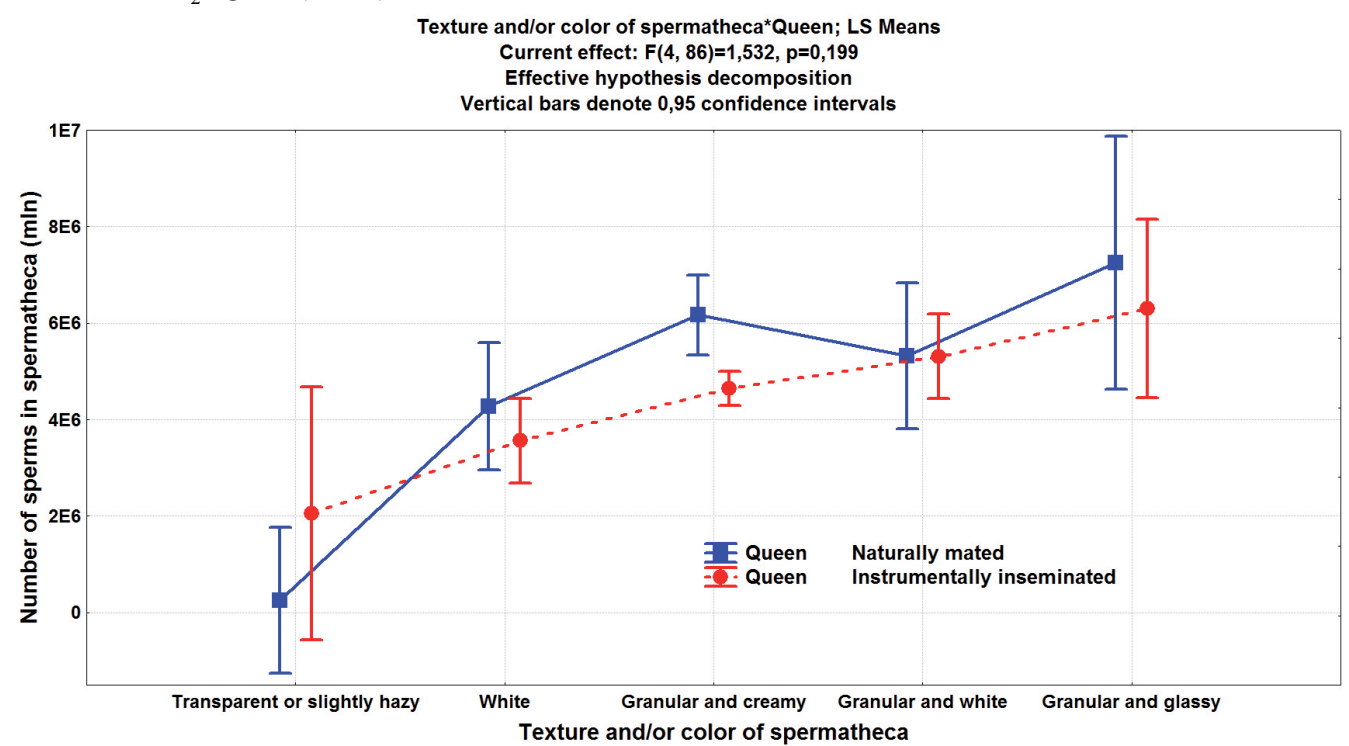

Fig. 1. Interaction between the texture and/or color of spermatheca and technique of insemination, on the number of sperm in the spermatheca. 
Table 4 .

Number of spermatozoa in the spermathecae of queens instrumentally inseminated at various ages, regardless of the oviposition

\begin{tabular}{|c|c|c|c|c|c||}
\hline \multirow{2}{*}{$\begin{array}{c}\text { Age of queens at } \\
\text { insemination }\end{array}$} & \multirow{2}{*}{$\begin{array}{c}\text { No. of } \\
\text { queens }\end{array}$} & \multicolumn{4}{|c|}{ Number of spermatozoa in the spermatheca $(\mathrm{mln})$} \\
\cline { 3 - 6 } & & Min & Max & Mean* & SD \\
\hline $5-6$ & 15 & 1.650 & 6.645 & $4.350 \mathrm{a}$ & 1.313 \\
\hline 7 & 56 & 2.000 & 9.125 & $5.251 \mathrm{a}$ & 1.681 \\
\hline $8-9$ & 25 & 2.650 & 6.650 & $4.771 \mathrm{a}$ & 1.211 \\
\hline $10-16$ & 16 & 1.600 & 6.650 & $4.518 \mathrm{a}$ & 1.402 \\
\hline Total & 112 & 1.600 & 9.125 & 4.918 & 1.526 \\
\hline
\end{tabular}

*different letters indicate significant differences at $\alpha=0.05, F(3,108)=2.085, p=0.106$.

Table 5 .

The number of spermatozoa in spermathecae of queens in relation to length of time between instrumental insemination and oviposition

\begin{tabular}{|c|c|c|c|c|c|}
\hline \multirow{2}{*}{$\begin{array}{c}\text { Length of time between } \\
\text { insemination and oviposition }\end{array}$} & \multirow{2}{*}{$\begin{array}{c}\text { No. of } \\
\text { queens }\end{array}$} & \multicolumn{4}{|c|}{ Number of spermatozoa in the spermatheca $(\mathrm{mln})$} \\
\cline { 5 - 7 } & & Min & Max & Mean* $^{*}$ & SD \\
\hline $3-9$ & 18 & 2.000 & 7.300 & $4.647 \mathrm{a}$ & 1.491 \\
\hline $10-16$ & 23 & 2.700 & 9.125 & $5.351 \mathrm{a}$ & 1.491 \\
\hline $17-23$ & 19 & 1.600 & 7.750 & $5.642 \mathrm{a}$ & 1.353 \\
\hline $24-33$ & 12 & 3.800 & 8.300 & $5.752 \mathrm{a}$ & 1.271 \\
\hline Total $^{* *}$ & 72 & 1.600 & 9.125 & 5.318 & 1.453 \\
\hline
\end{tabular}

*different letters indicate significant differences at $\alpha=0.05, F(3,68)=2.041, p=0.116$.

** only egg laying queens.

Number of spermatozoa in spermatheca of queens in relation to the age of queen at instrumental insemination, and the length of time between insemination and oviposition

Queens were inseminated at the age of 5 to 16 days (Tab.4). No significant differences were found in the number of spermatozoa in the spermatheca of queens inseminated at different ages. However, instrumentally inseminated queens at the age of 7 days old, had a higher number of spermatozoa. Among 56 inseminated individuals when 7 days old, as many as 40 were from 2 .II $7 \mathrm{CO}_{2} \mathrm{~L}$ and $3 . I I 7 \mathrm{CO}_{2} \mathrm{~S}$, and these queens were inseminated at the scheduled time, regardless of the flight activity. The remaining 16 queens were from 4.IItMF and 5.IIa1F groups, where the time of insemination depended upon their flight activity.

The first queens began oviposition just 3 days after insemination, while the last - after 33 days. However, there no significant differences were found in the average number of spermatozoa in the spermathecae (Tab. 5).

\section{DISCUSSION}

The number of spermatozoa in the spermatheca of queens was similar between particular groups of queens. Insemination of queens who had tried to perform a flight or who had performed a first flight, did not affect the process of semen migration from the oviducts to spermathecae. Some of the queens, among both the naturally mated or instrumentally inseminated, never started oviposition. These queens had significantly fewer spermatozoa in their spermathecae than egg laying individuals. The greatest disparity between laying and non-laying queens was noted among the naturally mated queens. An explanation concerning those queens which did not start oviposition could be the low number of spermatozoa in their spermathecae. Instrumentally inseminated queens probably had enough spermatozoa in their 
spermathecae, however they did not start egg laying.

The texture and color of the spermathecae after tracheal tissue was removed is a clear indicator of the insemination quality. Wellfilled spermathecae are white to cream with a distinct texture, while spermathecae of non-inseminated queens or not wellfilled queens are transparent or slightly hazy colored. Our observations are the same as in Cobey (2012) and Glenn (2012). The color and texture of the spermathecae depends only on the number of spermatozoa in them, regardless of the method of insemination, as shown in Fig. 1.

Most queens were inseminated at the optimum age for semen migration into the spermathecae. According to Woyke and Jasiński (1976), the optimum age is between 4 to 14 days. They stated that queens which were inseminated at the age of 14 days or older had significantly fewer spermatozoa in their spermathecae, whereas in our study the number of spermatozoa was not dependent on the age of instrumentally inseminated queens ( 5 to 16 days old).

Woyke and Jasiński investigating queens 4 to 47 days old, and Bieńkowska et al. (2008) investigating queens 5 to 10 days old showed that migration of spermatozoa from the oviducts into the spermathecae is most effective when queens are 4-5 days old and it decreases with the age of queens. In our study of queens 5 to 16 days old, there was no such regularity. Nevertheless, we found that absolutely the highest number of spermatozoa was in spermatheca of queens inseminated at the age of 7 days. The reason is probably because most of our experimental queens were inseminated when they tried to make the flight or after performing first flight. This was their way of demonstrating their readiness to accept semen.

The number of spermatozoa did not affect the time to oviposition. Queens started laying eggs 3 to 33 days after insemination and the number of spermatozoa in queen spermathecae was similar (Tab. 5).
The data show that this factor does not influence the time between insemination and oviposition. This is in accordance with Kaftanoglu and Peng (1982), who brought on oviposition when they exposed virgin queens to a $\mathrm{CO}_{2}$ treatment.

In our study, naturally mated and instrumentally inseminated queens had a similar number of spermatozoa in their spermathecae. Different results were obtained by Mackensen and Roberts (1948), Woyke (1960), Harbo (1986) and Wilde (1994), who reported a higher number of spermatozoa in naturally mated queens. Differentiation in the number of spermatozoa in the spermathecae was higher in naturally mated queens than in instrumentally inseminated queens according to these researchers. This indicates the big influence of external conditions on the success of mating. In instrumentally inseminated queens, these conditions are more stable and standardized.

\section{CONCLUSIONS}

Queens inseminated when attempting to perform flights, or after the first flight, had a similar number of spermatozoa in their spermathecae. Queens inseminated at the age of 7 days, and the queens naturally mated also had a similar number of spermatozoa in their spermathecae.

A significant correlation was stated between the color and texture of spermathecae and the number of spermatozoa in the spermathecae, however, the appearance of the spermathecae is not dependent on the method of insemination.

Instrumentally inseminated but nonegg laying queens had significantly fewer spermatozoa in their spermathecae than egg laying individuals.

Queens instrumentally inseminated at different age (6 to 16 days old) had similar number of spermatozoa in the spermathecae.

The length of time between instrumental insemination of queens and starting oviposition is not affected by the number of spermatozoa in the spermathecae. 


\section{REFERENCES}

Bieńkowska M., Panasiuk B. (2006) Influence of the diameter of the inseminating needle tip on the results of bee queens' fertilization. J. Apic. Sci., 50(2): 137-145.

Bieńkowska M., Węgrzynowicz P., Panasiuk B., Gerula D., Loc K. (2008) - Influence of the age of honey bee queens and dose of semen on condition of instrumentally inseminated queens kept in cages with 25 worker bees in bee colonies. J. Apic. Sci., 52(2): 23-33.

Cobey S. W. (2012) - Field Dissection of the spermatheca, [online] http://www. honeybee.breeding.com/HBIS/pdf/4. SpermathecaDissection.pdf (accessed on 28 February 2012).

Ebadi R., Garry N. E. (1980) - Factors affecting survival, migration of spermatozoa and onset of oviposition in instrumentally inseminated queen honeybees. J. Apic. Res., 19(2): 96-104.

Gerula D., Bieńkowska M., Panasiuk B. (2011) - Instrumental insemination of honey bee queens during flight activity predisposition period 1. Onset of oviposition. J. Apic. Sci., 55(2): 53-66.

Glenn T. (2012) - Diagnosis of failing queens by inspecting the spermatheca, [online] http://www.Glenn-apiaries.com/sperm.html (accessed on 28 February 2012).

Gontarz A., Bieńkowska M., Loc K. (2005) - Effect of queen caging condition on insemination results. J. Apic. Sci., 49(1): 5-15.

Harbo J. R. (1986) - Propagation and instrumental insemination, in: Renderer T.E.(Ed.), Bee Breeding and Genetics, Academic Press, Inc., pp. 361-389.

Janoušek J. (1987) - Effect of carbon dioxide on initiation of oviposition of inseminated queens. Vedecke Prace, V.U.V. v Dole, 9: 57-64.

Kaftanoglu O., Peng V. S. (1982) - Effects of insemination on the initiation of oviposition in the queen honeybee. J. Apic. Res., 21(1): 3-6.
Konopacka Z. (1991) - Wpływ narkozy $\mathrm{CO}_{2} \mathrm{i}$ $\mathrm{N}_{2} \mathrm{O}$ na wyniki sztucznego unasieniania matek pszczelich. [Effect of $\mathrm{CO}_{2}$ and $\mathrm{N}_{2} \mathrm{O}$ anaesthetics on the results of instrumental insemination of honey bee queens - in Polish]. Pszczeln. Zesz. Nauk., 35: 3-18.

Laidlaw H. H. (1954) - Beekeeping management for bee breeder. Am. Bee J., 94(3): 93-95.

Mackensen O. (1947) - Effect of carbon dioxide on initial oviposition of artificially inseminated and virgin queens bees. J. Econ. Enotmol., 40: 344-349.

Mackensen O. (1964) - Relation of semen volume to success in artificial insemination of queen honey bee. J. Econ. Entomol., 57(4): 581-583.

Mackensen O., Roberts W. C. (1948) - A manual for the artificial insemination of queen bees. US Bureau of Entomology and Plant Quar., ET-250.

Prabucki J., Jasiński Z., ChudaMickiewicz B. (1987) - The results of mass insemination of bee queens inseminated onefold and twofold and stocked in different ways. XXX Intern. Apicult. Congr., Warsaw: 169-174.

Wilde J. (1994) - Wpływ sposobu przetrzymywania matek pszczelich przed i po inseminacji na rezultaty tego zabiegu. [The effect of the method of keeping honeybee queens before and after the insemination on the results - in Polish]. Acta Acad. Agricult. Tech. Olst. Zootechnica, 39: 153-166.

Woyke J. (1960) - Naturalne i sztuczne unasienianie matek pszczelich. [Natural and artificial insemination of queen bees - in Polish]. Pszczeln. Zesz. Nauk., 4: 183-275.

Woyke J. (1979) - Effect of access of worker honeybees to the queen on the results of instrument al insemination. J. Apic Res., 19(2): 136-143

Woyke J. Fliszkiewicz C., Jasiński Z. (2001) - Prevention of natural mating of instrumentally inseminated queen honey bees by proper method on instrumental insemination. J. Apic. Sci., 45: 101-114. 
Woyke J., Jasiński Z. (1973) - Influence of external conditions on the number of spermatozoa entering the spermatheca of instrumentally inseminated honeybee queens. J. Apic. Res., 12(3): 145-151.

Woyke J., Jasiński Z. (1976) - The influence of age of the results of instrument al insemination of honeybee queens. Apidologie, 7(4): 301-306.
Woyke J., Jasiński Z. (1978) - Influence of age of drones of the results of instrumental insemination of honeybee queens. Apidologie, 9(3): 203-212.

Woyke J., Jasiński Z. (1979) - Number of worker bees necessary to attend instrumentally inseminated queens kept in an incubator. Apidologie, 9(3): 203-212.

\title{
SZTUCZNE UNASIENIANIE MATEK PSZCZELICH W OKRESIE AKTYWNOŚCI LOTNEJ \\ 2. LICZBA PLEMNIKÓW W ZBIORNICZKACH NASIENNYCH MATEK
}

\author{
Gerula D., Panasiuk B., Węgrzynowicz P., Bieńkowska M. \\ St r e s z c z e n i e
}

Badano, czy sztuczne unasienienie matek pszczelich w okresie kiedy próbują wykonać loty lub po wykonaniu przez nie pierwszych lotów, wpływa na liczbę plemników w ich zbiorniczkach nasiennych. Obserwacje wykonano w latach 2007-2008 i w 2010 w Instytucie Sadownictwa i Kwiaciarstwa w Puławach. Przebadano łącznie 133 matki pszczele rasy kaukaskiej. Przyjęte w ulikach matki podzielono losowo na 5 grup: grupę matek do naturalnego unasienienia, i 4 grupy doświadczalne matek sztucznie unasienionych nasieniem w ilości $8 \mu 1$, które różniły się terminem inseminacji, sposobem ich traktowania i długością narkozy $\mathrm{CO}_{2}$. Obserwowano następujące grupy matek: 1.NM - matki naturalnie unasienione, $2 . \mathrm{II}_{7} \mathrm{CO}_{2} \mathrm{~L}$ - matki sztucznie unasienione $\mathrm{w}$ wieku $7 \mathrm{dni}$ poddane narkozie $\mathrm{CO}_{2}, 3$ minuty w trakcie inseminacji i 3 minuty 2 doby po inseminacji, 3.II7CO $\mathrm{C}_{2}$ - matki sztucznie unasienione $\mathrm{w}$ wieku 7 dni poddane krótkiej narkozie $\mathrm{CO}_{2}$, około 30 sekund na czas wstrzyknięcia nasienia matkom, 4.IItMF - matki unasienione sztucznie kiedy próbowały wykonać swój pierwszy lot, poddane narkozie $\mathrm{CO}_{2}$ na około 30 sekund jw. oraz 5.IIa1F - matki sztucznie unasienione po pierwszym locie, poddane narkozie $\mathrm{CO}_{2}$ na około 30 sekund jw. Matki z poszczególnych grup miały podobną liczbę plemników w zbiorniczkach nasiennych, średnio od 4,7 do 5,3 mln. Stwierdzono istotnie różną liczbę plemników w zależność od koloru i wyglądu zewnętrznego zbiorniczków nasiennych. Najwięcej plemników miały matki, u których zbiorniczek nasienny miał wyraźną ziarnistą strukturę zewnętrzną o zabarwieniu białym lub kremowym oraz z charakterystycznym połyskiem. Najmniej plemników miały te matki, u których zbiorniczek był lekko mętny lub biały bez wyraźnej struktury zewnętrznej. Matki unasienione ale nieczerwiące miały istotnie mniej plemników $(3,9 \mathrm{mln}) \mathrm{w}$ zbiorniczkach nasiennych niż matki czerwiące $(5,5 \mathrm{mln})$. Matki unasieniane w różnym wieku: 5-16 dni miały podobną liczbę plemników w zbiorniczkach nasiennych. Nie stwierdzono, aby liczba plemników w zbiorniczkach nasiennych matek wpływała na długość okresu od unasienienia do rozpoczęcia czerwienia.

Słowa kluczowe: pszczoła miodna, liczba plemników w zbiorniczkach nasiennych, inseminacja, aktywność lotna, naturalne unasienianie, tekstura i kolor zbiorniczka nasiennego. 